\title{
Constructing Finno-Ugric Identity through Theatre
}

\section{LUULE EPNER, ANNELI SARO}

\begin{abstract}
The article investigates the construction of transnational Finno-Ugric identity through the theatre festival Mayatul and different performative strategies. This kind of identity construction is investigated through the framework of identity politics and transnationalism. The definition of the Finno-Ugric peoples (Finns, Estonians, Hungarians, Samis, Mordvins, Komi, Udmurts and others) is based foremost on their language kinship. It is believed that similar characteristics of languages and a similar natural environment and climate have shaped the close-to-nature lifestyle and the particular perception of the world shared by the Finno-Ugric peoples.

Essential platforms for constructing transnational Finno-Ugric identity are different theatre festivals, among which Mayatul (since 1992) is the most prominent. The majority of productions at the festival are performed in FinnoUgric languages and interpret the literary texts or folklore of these peoples. However, only a few productions strive for indigenous aesthetics like those of Estonian theatre director Anne Türnpu.

The Finno-Ugric peoples' identity is predominantly a minority identity because mostly they represent a small national and language group in a bigger state like Russia, and only Finland and Hungary have enjoyed one hundred years of independence. Nevertheless, all countries and nations embrace smaller ethnic or cultural minorities, thus minority identity is a universal concept. Theatre festivals are able to unite minority identities into larger transnational identites, even when it is just an imagined community.
\end{abstract}

\section{KEYWORDS}

Finno-Ugric identity, minority identity, transnational performance, Estonian theatre, Mayatul, Anne Türnpu. 


\section{Constructing Finno-Ugric Identity through Theatre ${ }^{1}$}

\section{Constructing Finno-Ugric Identity through Theatre}

There are about twenty-four different peoples speaking the Finno-Ugric languages but their political status varies greatly. Only the three largest Finno-Ugric peoples have their own independent nation state: Hungarians (about 15 million speakers), Finns (5 million) and Estonians (1 million). The majority of them, however, have never had their own state, although they are the indigenous inhabitants of the territories where they live. The Sami people inhabit northern parts of Norway, Sweden and Finland, Mordvins (Erzya and Moksha), Maris, Karelians, Udmurts, Khanty, Mansis, Komi, Vepsians are living in Russia. They are recognized as national minorities and most of them have their own autonomous republics or autonomous regions, but even in these regions, the Finno-Ugric peoples represent a minority; with a few exceptions. ${ }^{2}$

The article investigates the construction of Finno-Ugric identity through a theatre festival and different performative strategies and is divided into four parts. First, some principles of construction of national and transnational identities are introduced. After that, the kinship movement of the Finno-Ugric peoples is investigated in a historical perspective and in the framework of identity politics. In the third part, we analyze how the transnational FinnoUgric identity is manifested at the international theatre festival Mayatul of the Finno-Ugric peoples. Finally, we follow Estonian stage director Anne Türnpu in her search for an indigenous aesthetics that would correlate with FinnoUgric mentality.

\section{(Trans)national Identities}

Identities, including national identities are commonly regarded as constructed and processual, in line with Stuart Hall's now generally accepted approach. Hall argues that identities in late modern times are increasingly fragmented and

1 This work was supported by the Kone Foundation, the Estonian Research Council, grant PRG636 and by the University of Tartu, grant PHVKU20933.

2 Eesti rahvaluule webpage. 
multiple, constructed across different discourses, practices, and positions; they are "constantly in the process of change and transformation." 3 The dynamics of national identities have become a particularly debated topic in recent decades since the formation of these identities is largely affected by broader social processes such as globalization, mass migration, multiculturalism, etc. Additionally, the collapse of the Soviet Union and the revolutions in EasternEuropean communist states in the late 1980s and in the early 1990s brought about, among other things, a destabilization of many traditional collective identities. As a result of all these sociopolitical and economic developments, cultural identities have become increasingly fluid and hybrid; frequently, they are felt as sites of ambivalence. "One becomes aware that 'belonging' and 'identity' are not cut in rock, that they are not secured by a lifelong guarantee, that they are eminently negotiable and revocable," says Zygmunt Bauman. ${ }^{4}$

To be sure, while national identity remains a significant conceptual category in the contemporary rapidly changing world, there is no reason to cast the concept into the garbage heap of history as something old-fashioned. Despite "the creeping globalization of media and technology", national cultures and local traditions continuously provide structures of meaning and identification for people, as has been stated by theatre scholar Janelle Reinelt. ${ }^{5}$ Furthermore, the tendency of localization, which values local uniqueness and strives to preserve indigenous cultural practices and traditions, often intertwines with and counterbalances the trend of globalization. Although national cultures are part of the global world, the elements and criteria of national identities are, nonetheless, subject to constant negotiation and re-evaluation.

As we know, identity (including national identity) is about differences between 'us' and 'them', about marking symbolic boundaries that separate virtual (imagined) communities. This occurs on several levels and in different dimensions. Concerning the wider spatial (cultural geographical) dimension, the question is to which broader cultural region do nations think they belong. Within this, transnational narratives are produced, negotiated and related alongside national and local identities. Like other layers of identity, a transnational identity of this kind is never unified, the one and only for all times and all members of a community. Alternative, even competing identity narratives, are available, since symbolic cultural boundaries are set in many ways, new identity narratives are invented, and dominant narratives are undermined.

In today's European countries, transnational belonging is ordinarily and most closely associated with European identity - no matter how problematic such a broad concept can be. ${ }^{6}$ As far as Estonians are concerned, the cultural movement Young Estonia (Noor-Eesti) that emerged at the beginning of the twentieth century, set the slogan, which established itself in the cultural consciousness of subsequent generations of Estonians: "Let us be Estonians,

\footnotetext{
3 Hall 1996, 4.

4 Bauman 2004, 11.

5 Reinelt 2005, 370.

6 See Thiel and Friedman 2012, 1.
} 
but also become Europeans!" Thus, Europeanization (i.e. modernization) of national culture was set as a goal. Later, however, the idea of Estonians belonging to Europe has been questioned over and over again - the trend of Europeanization has been repeatedly resisted. Indeed, there are other, although narrower cultural areas, to which Estonians are also affiliated. The idea of Estonians as a Finno-Ugric people thus offers an alternative (or provides an additional layer) to the European transnational identity. Next we will take a closer look at how transnational Finno-Ugric identity has been constructed.

\section{Finno-Ugric Peoples and the Finno-Ugric Kinship Movement}

The definition of the Finno-Ugric peoples is based foremost on language kinship - their belonging to the Finno-Ugric language family. ${ }^{8}$ Since the structure of these languages (for instance, they lack the future tense of verbs and grammatical gender) has affected the thinking of its people, it is believed that the Finno-Ugric peoples share essential similarities in their mentalities and traditional culture. ${ }^{9}$ These language characteristics, as well as a fairly similar natural environment and climate, have shaped the close-to-nature lifestyle and the particular perception of the world of the Finno-Ugric peoples - the sense, which involves a permanently lasting present, non-linear, and non-hierarchical patterns of perception, easy acceptance of paradoxes and contradictions, etc. ${ }^{10}$

Linguistically, similar languages and close ways of perceiving the world are, of course, a good basis for the formation of transnational identity. But language kinship does not provide a common tool for communication and geographical distances have hindered much cultural interaction. The political and cultural histories of people also vary from each other to a considerable extent. Thus, Finno-Ugric identity is highly hypothetical and imaginary.

According to the Russian census data of 2002, the number of FinnoUgrians has decreased from 3.3 million in 1989 to 2.7 million. However, the number of actual speakers of the Finno-Ugric languages in Russia has decreased to under two million and this number keeps declining. ${ }^{11}$ The main reasons seem to be rapid urbanization, migratory trends, mixed marriages, and the downgrading of native language education: indeed, it is not possible everywhere to attain even primary education in their mother-tongues. The Finno-Ugric peoples in Russia have had very limited opportunities to develop or even preserve their languages and cultures. Thus, the Finno-Ugric peoples' sense of shared identity is predominantly not just a minority identity, but also

7 Suits $2002,70$.

8 Finno-Ugric languages belong, in turn, to the larger family of Uralic languages that are spoken by Northern or Boreal peoples (incl., among others, indigenous peoples in Siberia and Northern America). This makes it possible to expand Finno-Ugrianism towards the larger North-Eurasian cultural area and to speak of the affinity with Boreals ("forest peoples") as opposed to the IndoEuropeans.

9 Eesti rahvaluule webpage, Masing 1993.

10 Masing 1993. (See also Sallamaa 1999.)

11 "Finno-Ugric Peoples." Fenno-Ugria webpage. 
an endangered one, at least in some countries.

As noted above, in Estonia, Finno-Ugrianism has functioned as the alternative option to self-definition. As the Estonian anthropologist Kristin Kuutma observes: "The alternative self-definition (...) embraces the evolution and maintenance of a Finno-Ugric identity that was perceived to carry the original essence of Estonian-ness, and to safeguard against a threatening dominant 'other'", 12 whether that was Baltic German, Russian or the Soviet hegemony.

Close linguistic and cultural kinship with Finns has played a crucial role in shaping the national identity since the period of early Estonian nationalism at the end of the nineteenth century, while interest in other Finno-Ugric peoples has remained relatively weak. In independent Estonia, particularly since the late 1920s, the "kindred people's movement", which was coordinated by the Fenno-Ugria, ${ }^{13}$ enjoyed high national prestige and was strongly supported by the governments of Estonia, Finland, and Hungary. Fenno-Ugria organized a wide range of activities to promote cultural cooperation between the three countries. ${ }^{14}$ At the same time, contacts with Finno-Ugric peoples living in Soviet Russia remained very limited for political reasons. After the Soviet occupation in 1940, however, Fenno-Ugria was closed and the notion of a kindred people's movement was banned from public discourse, although, in the period that followed, new direct contacts with the eastern Finno-Ugric peoples living in Russia were established. This period in particular witnessed an increase in academic contacts, including research expeditions to FinnoUgric peoples by linguists, folklorists, and ethnographers. At the end of the 1970s, the tradition of research expeditions of art students began, which has significantly enhanced a Finno-Ugric sensibility in Estonian art. ${ }^{15}$ In the late Soviet period, the image of an Estonian as a Finno-Ugrian began to spread more widely; a manifestation of Finno-Ugric identity in the arts became a political instrument to express an oppressed national selfhood. ${ }^{16}$

The Soviet nationality policy in the 1970s and the 1980s was characterized by an increasing tension between ethnic identities and the hegemonic concept of a kind of supranational "Soviet people”, which was vigorously imposed by the Soviet authorities and institutions and which, in practice, meant a processed Russification. Policies toward the Finno-Ugric peoples, as well as other non-Russian nationalities, favoured a transition from native languages to Russian. The pressure for social assimilation increased. At the end of the 1980s, perestroika brought about a new national awakening, both in the Baltic republics and among the Finno-Ugric peoples living in Russia. In Estonia,

12 Kuutma 2005, 54.

13 The non-profit organisation Fenno-Ugria is an umbrella organisation dedicated to cooperation with Estonians' kindred peoples - the Finno-Ugric and Samoyedic peoples. Fenno-Ugria was established in 1927 and re-established in 1991.

14 Prozes 2012.

15 Arukask 2018, 110-111.

16 See Kuutma 2005, 55-56. Telling examples from the 1970s and the 1980s are the interpretations of the Finno-Ugric musical heritage by Veljo Tormis, the graphic works by Kaljo Põllu, the books and documentaries by Lennart Meri, and the theatrical experiments of Jaan Tooming. 
this period saw a rapid upswing in the interest for Finno-Ugric kinship and the cooperation with kindred peoples in Russia: the tradition of an annual Finno-Ugrian Day (celebrated in 1928-1940) was revived in 1988, several national societies redefining Finno-Ugric links were established, national congresses of the Finno-Ugric peoples were organized and the Fenno-Ugria was restored. ${ }^{17}$ Before World War II, cooperation between Estonia, Finland, and Hungary had been at the core of the Finno-Ugric project; but after the 1990s, the focus shifted to cultural and educational relations with the FinnoUgric peoples of the Russian Federation. ${ }^{18}$

It was during this politically turbulent period of national awakening that the Finno-Ugric theatre festival was established.

\section{Performing Finno-Ugric Identity through the Theatre Festival}

As mentioned above, national identity is based on ethnic bonds, and composed of numerous components, including common myths, historical narratives, traditions, beliefs, etc. that form its symbolic and affective aspects, which serve as a basis for the individual's emotional connection with the nation. ${ }^{19}$ These aspects are naturally subject to construction, de- and reconstruction through the arts, including the theatre. Indeed, as Nadine Holdsworth says, the theatre, "taking place in a communal public arena, can be one of the ways that members of a nation contribute to public discourse, a national conversation, which opens up the possibility for reflection and debate." 20 Stage productions can be the sites in which the issues of national affiliation can be addressed - the places to revisit cultural imagery they are based on, to strengthen identity, or to problematize the habitual ideas around national belonging, and so on. As regards transnational identities, this performativediscursive aspect is important in their formation, since cultural expressions that transcend borders "have the potential to create a sense of transnational belonging." 21

Theatre festivals, like any festival, can serve the manifestation of ethnicity as means of demonstrating and experiencing a particular identity. A festival is a cultural performance, which occurs at regular intervals, is temporally and spatially bound, programmed, and characterized by coordinated public occasions. ${ }^{22}$ As a festival is public in nature, festive performances are communicative; they actively engage participants, offer shared experiences, and establish social cohesion. The expression of group identity is one of their prime purposes. In the words of anthropologist Beverly J. Stoeltje, "festival brings the group together and communicates about the society itself and the role of the individual within it." ${ }^{23}$ Festivals are thus likely to be able to create "imagined communities", uniting minority identities into a broader transnational

17 Prozes 2012, 110-111.

18 Prozes 2014, 17.

19 Smith 1991, 162.

20 Holdsworth 2014, 2.

21 Thiel and Friedman 2012, 2.

22 Kuutma 1998.

23 Stoeltje 1992, 263. 
identity.

Those theatre festivals that bring together theatres and groups from almost all the regions in which the Finno-Ugric peoples live are supposed to be essential platforms for constructing Finno-Ugric identity. Since 1997, the international theatre festival of the Finno-Ugric peoples, Mayatul (hearthfire) ${ }^{24}$, has become a central meeting place partly because of its long tradition. The first festival took place in Iževsk, Udmurtia in 1992, as part of a festival project of the minorities living in the Russian Federation. It was launched by the $M$. Shketan Mari National Theatre and the Ministry of Culture of Mari EI Republic, and received support from the Ministry of Culture of the Russian Federation and the international Finno-Ugric Foundation. The social background was the vigorous rise in national self-awareness in Russia which, during this period, had fostered the establishment of other language-based festivals as well (eg. Turkish, Mongolian, etc.). ${ }^{25}$

As Henri Schoenmakers has pointed out, theatre festivals are meta-events that organize and present single productions according to certain principles: "Such an integrating principle is of great help to evoke the feeling that we are dealing with a recognisable identity at the level of the festival as "meta-event." 26 All the productions presented in the framework of the theatre festival of the Finno-Ugric peoples could thus be considered formally as representatives of Finno-Ugric theatre as a whole. The organizers of Mayatul seem to have accepted everyone coming from all the countries in which the Finno-Ugric languages are spoken.

One characteristic feature of Finno-Ugric theatre is that the performances often involve a blending of Finno-Ugric cultural material. ${ }^{27}$ For example, in 1992, the Grand Prix of the festival was awarded to the Mari National Theatre's Outbreak, which was based on the play by Mordovian writer Alexander Pudin and in 2010, to the Puppet Theatre Centre Poiju from Finland for their production Cygnet Jykserge, which was based on Mari mythology. In short, it became typical for the theatre groups to perform not only their own original plays, but also the work of kindred peoples. This also means that the cultural exchange and mirroring that occurs during rehearsals and the festival itself is also of importance.

After the first festival, the dramaturg of the Estonian Drama Theatre Andres Laasik expressed his deep skepticism about the Finno-Ugric movement, captioning his review with the heading "Theatre Feast of Dying Nations", claiming that as a matter of fact there is no Finno-Ugric unity. ${ }^{28}$ The festival nonetheless continued, if rather irregularly during the 1990s. The second festival took place in 1994 in Nurmes, Finland and the third in 1997 in the capital city of the Mari El Republic Yoshkar-Ola. After a five-year break the

24 The root of this word "tul" ("fire") is common to all Finno-Ugric languages (cf. Fin. Tuli , Hungarian tüz). (ETY)

25 Kulbayeva Финно-угорский культурный центр Российской Федерации webpage 2009.

26 Schoenmakers 2007, 28.

27 All observations of the festival made by the authors are based on different electronic media texts in Russian, Estonian, Finnish, and English, if not referred to otherwise.

28 Laasik 1992, 64. 
fourth festival followed in 2002 and since then the event has been organized regularly every second year in Yoshkar-Ola (with the exception of 2012, when it took place in Saransk, the capital of the Republic of Mordovia).

According to different festival invitations and press releases, the direct aims of the theatre festivals of the Finno-Ugric peoples are to launch artistic dialogue, to foster collaboration between participants, and to present the best productions in the native languages. The festivals nonetheless have a more far-reaching, even political ambition to support the preservation and development of the Finno-Ugric languages and a sense of common identity. In the following, we will ask whether and how these goals have been achieved at the Mayatul festival.

The Mayatul festival is currently organized by various high level cultural institutions: the Government of the Mari El Republic, the Ministry of Culture of Russia, the Ministry of Culture, Media and International Relations of the Mari Republic and the Mari National Theatre. The participants of the festival are mostly theatres working in Finno-Ugric languages, that is a few institutions from Central Russia (the M. Shketan Mari National Drama Theater, the State National Theatre of the Udmurt Republic, the Komi State Academic Drama Theatre, the Komi-Permyak Drama Theatre in Kudymkar, etc.) and NorthEastern Russia (the National Theatre of Karelia) and various groups from Finland, Estonia, and Hungary. The theatres located in Russia offer mostly single productions in the Finno-Ugric languages in their repertoire or produce a work specially for the festival. ${ }^{29}$ This means the selection base for the festival performances is quite narrow. Contrary to this, those representatives from Finland, Estonia, and Hungary (the most rare visitor at Mayatul), come from a broad spectrum of different theatres and productions, meaning that what is performed is sometimes quite accidental in the context of the festival. Personal initiative seems to be the most decisive factor in the groups attending the event. Since the festival does not cover travel costs, these groups coming from distant countries consist often of one to three performers. According to the collected data by the authors, the heart of the festival is the FinnoUgric peoples who live in Russia, while the presence of Estonia, Finland, and Hungary has been irregular and somewhat random.

In the following, three key elements of the theatrical events that represent Finno-Ugric identity and theatre aesthetics will be examined.

1. Language. The actors perform generally, but not exclusively, ${ }^{30}$ in their native languages. Indeed, keeping the small Finno-Ugric languages alive is considered to be one of the main endeavors of the festival. While language is truly critical for preserving Finno-Ugric identity in Russia, the "national" theatres of the Finno-Ugric peoples normally work in the Russian language because their leaders and stage directors are mostly Russians. Indeed, not all the indigenous actors are able to play in their native language and may prefer

29 Türnpu 5.2.2020.

30 For example, Asko Sarkola's (Lilla Teatern) mono-performance in Swedish represented Finland in 1992 and in 2012, the Grand Prix was given to Black Song, the only Russian-language production in this festival - the songs of which were in Khanty. 
Russian. This means that sometimes actors just learn their lines by heart without any special attention on the pronunciation (especially in productions of Karelian or Mordvin national theatres). ${ }^{31}$ Problems in understanding can therefore also take place. For instance, when Viia-Kadi Raudalainen, director of the Fenno-Ugria witnessed a Finnish-language performance, Mika Myllyaho's Chaos by the National Theatre of Karelia, it was difficult to understand because Finnish was not the mother tongue of any of the actors. ${ }^{32}$ Indeed, the working language of the Mayatul festival is also Russian and local audiences and festival guests are not able to follow different Finno-Ugric languages. Due to that, all performances are translated simultaneously into Russian, a language not spoken widely in Finland and Hungary and among young people in Estonia. It is no wonder that Kirsikka Moring, a prominent Finnish theatre critic and member of the jury said of the $9^{\text {th }}$ festival (2012), in which Estonian, Finnish, and Hungarian theatres did not participate: "This was not an international, but totally Russian [umbvene in Estonian] festival." 33

2. Repertory. The performances presented at the Finno-Ugric festivals can be roughly divided into three groups. According to our experience, similar patterns can also be found in performances of cultural minorities elsewhere in Europe.

A. Stage productions based on plays written in local languages which mostly tackle local (social) problems. The dramas and comedies of the FinnoUgric playwrights tend to depict mainly village life in a true-to-life style and often fulfill a didactic function. ${ }^{34}$ The Finno-Ugric peoples in Russia tend to live in the countryside and thus, the village is often their natural environment: this is also seen in the arts. The aesthetic conventions can be explained by the expectations of potential audiences.

B. Stage productions based on world classics and Russian plays (the smallest group). For instance Shakespeare's A Midsummer Night's Dream by the Mari National Theatre (2006) and Alexander Ostrovsky's The Snow Maiden by the same theatre (2018). These two strategies, A and B have been dominant in the creation of the "national repertoire" among the Finno-Ugric peoples living in Russia since the 1920s. ${ }^{35}$

C. Stage productions based on Finno-Ugric folklore and rituals. For instance, Elk-woman by Anne Türnpu or Hunting Lodge by the Komi theatre (both 2002). As Kirsikka Moring has commented: "Mordvins, Komis, Udmurts, Maris, Komipermyaks, Khanty and Mansis bring on the stage their history in national costumes, large ethnomusicals or ethnorock, national operas, ballads, epics and legends." 36

In the 1990s, it was especially common that theatres located in Russia would perform the works of Russian authors in indigenous languages or texts

31 Türnpu 21.3.2019.

32 Raudalainen 2019, 129.

33 Viluoja 2013, 145.

34 Kulbayeva Финно-угорский культурный центр Российской Федерации webpage 2009.

35 Cagnoli 2013, 4.

36 Moring Helsingin Sanomat, 25.11.2012. 


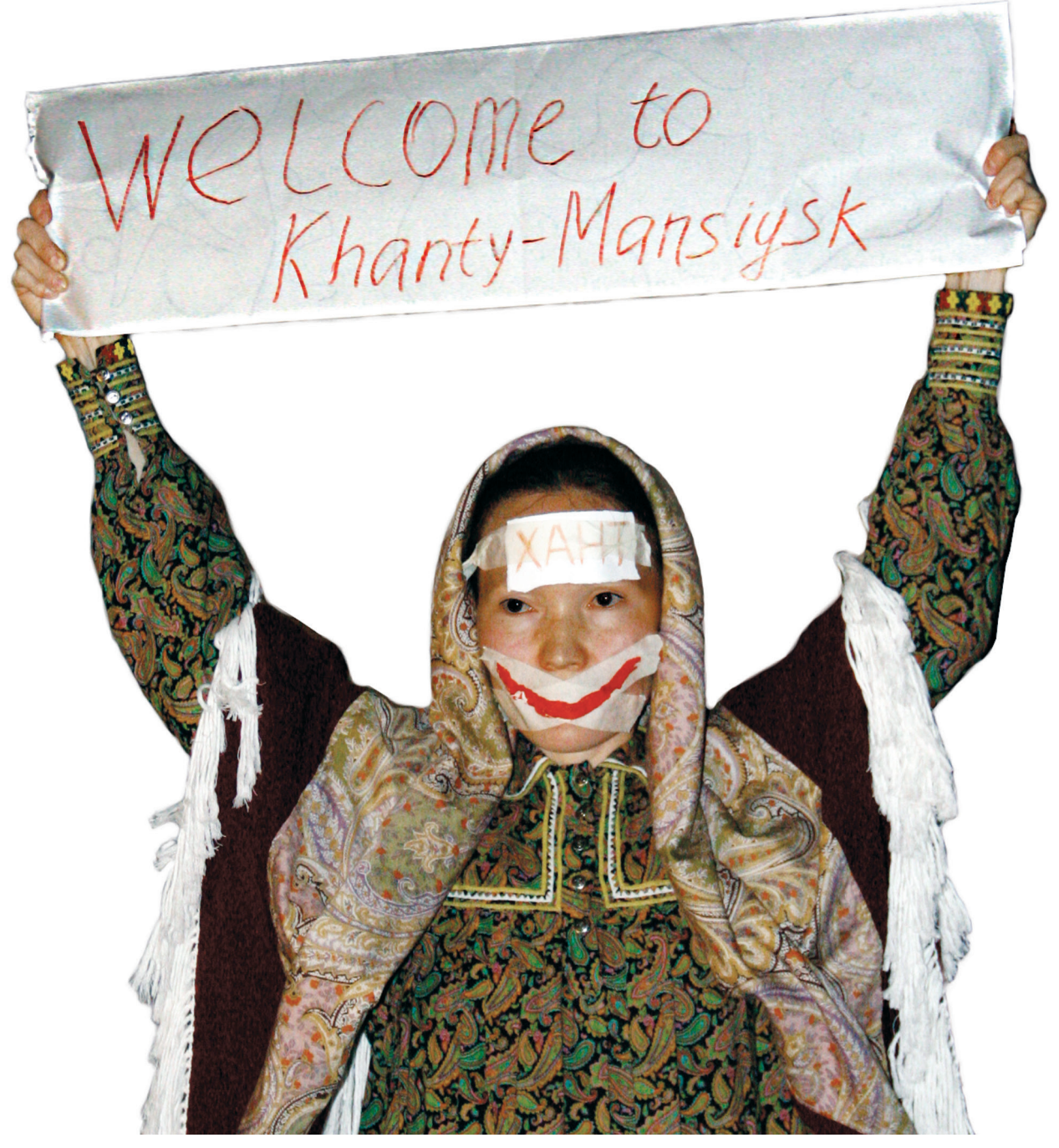

FIGURE 1. Jevgenia Moldanova. Sugrierror.com. Directed by Anne Türnpu, Eva Klemets (Koldits), Mart Koldits. NO99 StrawTheatre, 2011. Photo: Epp Kubu.

by local authors, in which folk songs, dances, rituals, traditional costumes, and musical instruments were inserted as decorative elements. ${ }^{37}$ This is a popular strategy, showing how foreign material can be domesticated. A turn to folklore and folk rituals took place at the turn of the century and this has now become the mainstream of the Finno-Ugric theatre. Quite frequently, however, cultural heritage and folk traditions are used in an out-of-context, non-authentic way in order to create rather decorative pseudo-ethnographic spectacles - the belief being that this is where the roots of the indigenous culture can be found. ${ }^{38}$

3. Theatre aesthetics. A further aim of the Finno-Ugric theatre movement has been to reach original theatre aesthetics. This task seems to be the hardest to achieve. Finno-Ugric actors and directors trained and working in Russia tend to rely mostly on the aesthetics of psychological realism, which is dominant in Russian theatres; distancing from the mainstream of realistic theatre is thus rare and, when it occurs, is mostly related to the stagings of Finno-Ugric folklore.

37 Türnpu 5.2.2020.

38 See Kirsikka Moring and Anne Türnpu in Viluoja 2013. 
The Estonian theatre director Anne Türnpu, who has regularly visited the festival and has staged productions based on Finno-Ugric folklore, believes that Stanislavski's system and the system of education in Russian theatre schools are not suitable to the psyche of the Finno-Ugric peoples. She compares mainstream trends in Finno-Ugric theatre with folklorism and assumes that the essence of Finno-Ugric theatre is to be found in the performativity of ancient rituals. ${ }^{39}$ This assumption needs some contextualization. In Russia, the Finno-Ugric languages are spoken predominantly in the countryside while the professional theatres are located in bigger cities where the majority of inhabitants are Russian-speaking. There is thus a chance that the professional Finno-Ugric theatres easily become alienated from the Finno-Ugric communities and living folk traditions. Unfortunately, amateur village theatres are not welcome at the Mayatul festival. ${ }^{40}$

Nevertheless, at the festival in 2016, Türnpu noticed a search for new tools of expression and new topics that might have the potential of reaching local communities. For example, the Komi-Permyak Drama Theatre in Kudymkar put on a production Cold Summer (director Stepan Pektejev) based on contemporary folklore related to death and performed in verbatim technique. The Kazym Bark Mask Theatre meanwhile initiated an applied theatre project designed to help Khanty children find their indigenous identity. ${ }^{41}$

Another repeated complaint is that the theatres can only go to the festival to give their own performances and therefore the actors are unable to watch each other's performances or take part in discussions. This means that the festival has not entirely fulfilled its purpose of being a meeting place and a place for the exchange of experiences of Finno-Ugric theatres. ${ }^{42}$ Or, from another angle: "Kinship is less a cause for the similarity of their cultural development today than a pretext for regular meetings (congresses, festivals)." ${ }^{33}$ Nevertheless, some artists are still devoted to exploring the Finno-Ugric heritage and transnational identity.

\section{Anne Türnpu: Sugrierror.com and How to Sell a Seto?}

Anne Türnpu (b. 1963) is an Estonian stage director and actor, who has consistently promoted cooperation between the Finno-Ugric peoples. In Estonia she is best known for practising and promoting so-called pärimusteater (theatre based on ethnic heritage). This kind of "heritage" theatre draws on archaic folklore heritage (folk music, customs, beliefs, everyday practices, folk costumes, etc.), usually combining elements built on a variety of traditions of kindred peoples, the aim being to redefine national identity. The interest in folklore runs parallel to the revival of regional culture that has been taking place in South-Eastern Estonia in particular, where local ethnic identities (like those of the Võru and Seto) are also being (re)constructed through the use of local

39 Türnpu 5.2.2020.

40 Türnpu 5.2.2020.

41 "Soome-ugri..." Fenno-Ugria webpage.

42 See Raudalainen 2019, Viluoja 2013.

43 Cagnoli 2013, 8. 
folklore, dialect, and the study of the cultural history of the region.

Türnpu's production, Sugrierror.com, came while being at the end of a rather long process. It started as a training project for Finno-Ugric actors initiated by Fenno-Ugria. In 2010, a group of actors from Russia participated in classes and workshops held at the theatre school in Tallinn for two weeks and made a trip to Setomaa in South Estonia. The next year, the stage production was prepared and performed first of all as part of a program relating to Tallinn as the European Capital of Culture (2011), more specifically as part of the Straw Theatre program held under the auspices of Theatre N099. ${ }^{44}$ In 2012 , Sugrierror. com participated in the $9^{\text {th }}$ Mayatul festival. The main goal of the project was to encourage indigenous actors to develop their own theatrical language based on their specific ethnic identity and, therefore, in a different fashion from the Russian (Stanislavskian) tradition that still dominates their home theatres. ${ }^{45}$ Türnpu deliberately took identity as the main theme of the stage production. ${ }^{46}$ She had initially been interested in the differences between the Finno-Ugric peoples on a mental level because she felt that it was by understanding those differences that one could grasp the common and unifying aspects among the Finno-Ugric peoples. ${ }^{47}$

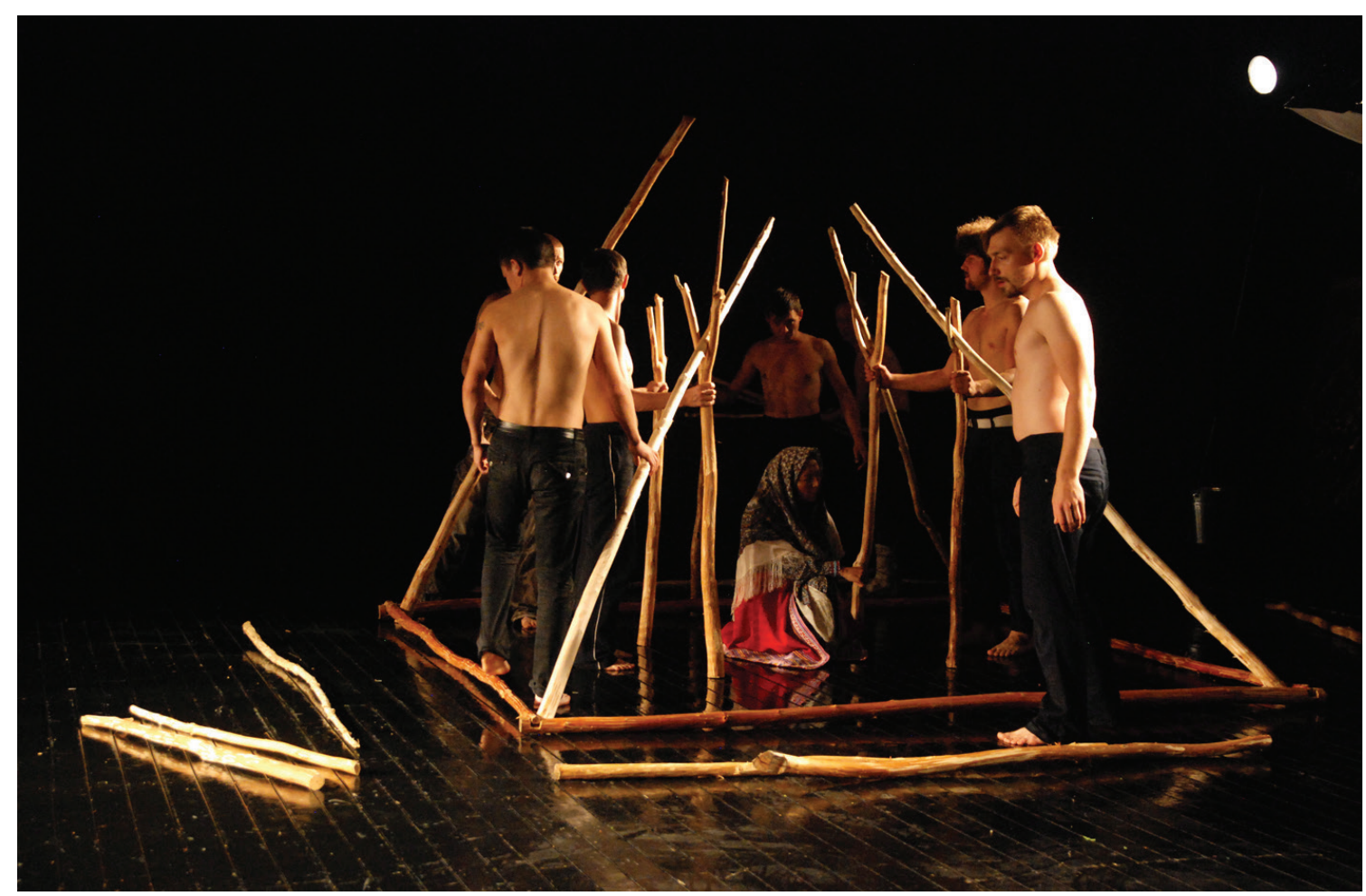

FIGURE 2. Sugrierror.com. Directed by Anne Türnpu, Eva Klemets (Koldits), Mart Koldits. NO99 StrawTheatre, 2011. Photo: Veiko Tubin.

44 With regard to the Straw Theatre see https://no99.ee/apu about-us/no99-straw-theatre.

45 See Türnpu and Heinapuu in Raudalainen 2012.

46 Linder Sirp 26.8.2011.

47 Raudalainen 2012. 
The troupe consisted of twelve Finno-Ugric actors: three Khanty, one Mansi, three Mari, one Udmurtian, three Estonian and one Seto performer. This combination of different Finno-Ugric cultures was typical of Türnpu's work, but quite unusual in the context of Finno-Ugric festivals. The actors were also people who still speak their own language and know their traditional culture the living rituals, customs, songs, etc. They brought along their own traditional texts, folk songs and tales, pieces of music, and based on this material they began to improvise and to produce etudes in collaboration with three Estonian directors: Türnpu herself, Eva Koldits, and Mart Koldits. Sugrierror.com was thus created by devising without using any pre-written text. (Originally it was even intended to be a purely improvisational performance, but due to lack of time, the structure of the performance ultimately became fixed. ${ }^{48}$ ) Theatrical language thus became an instrument for studying transnational Finno-Ugrian identity.

Sugrierror.com consisted of loosely bound scenes with the actors telling stories (some of them very personal), singing, playing folk music, and performing ethnic rituals like the Khanty bear worship (a funeral ceremony after the hunters have killed a bear), Mari prayers in the sacred grove and an Udmurtian funeral. In the background, northern nature (mainly forests and bogs), as well as contrasting images of the city were shown on the video screen. On the screen, the spectators saw, among other things, the image of bog boardwalks with tiny cars driving on them showing a visualized dissonance between nature and urban culture. The performance was nonetheless by no means just a reproduction of old traditional cultures. On the contrary, the Finno-Ugric world was contrasted and compared to a modern society in which indigenous culture has become a mere tourist attraction. The emotional tonality of these scenes had a sense of a bitter irony seen for example in a scene on the video-screen - Maris in national costumes routinely performing a folk dance at the opening of the Lukoil gas station; a monologue about a Seto auction in which items and ideas of Seto culture are put on sale; and Khanty people being photographed in a photo studio with patronizing comments from a photographer (an Estonian actor). The performance also included a selfreflexive monologue by the Udmurt actor about his work at his home theatre and the conflicts that occured with traditional village culture.

According to Türnpu, the word error in the production's title refers to the aesthetics of error, which reveals a shift or divide between reality and the (mental) world built by man. ${ }^{49}$ Error as the principle of contingency was embodied by a little Khanty girl, who was on stage throughout the performances and did whatever came to her mind.

Critics paid much attention to the way elements of archaic cultures were placed in juxtaposition to the modern sense of life, or "technological consciousness". 50 The performance's aesthetics were also associated with the concept of ethno

48 However, the festival performance in Saransk was different, since a number of actors were not able to participate in it. The stage production was awarded a prize as a bold theatrical experiment. See Viluoja 2013.

49 Linder Sirp 26.8.2011.

50 See for example Ala Postimees 31.8.2011. 
futurism ${ }^{51}$, well known in Estonia and Finland. ${ }^{52}$ Kirsikka Moring, inspired by the production, expressed the longing that Finno-Ugric theatres in Russia would start showing how people live today. ${ }^{53}$

The Finno-Ugric peoples' identity is predominantly a minority identity because they mostly represent a small national and language group in a larger state like Russia while only Finland and Hungary have enjoyed one hundred years of independence. Nevertheless, all countries and nations embrace smaller ethnic or cultural minorities, thus minority identity is a universal concept. Anne Türnpu has also investigated the self-perception of the Setos (an ethnic minority living in South-Eastern Estonia at the Russian border) in three other productions that were produced together with the Youth Studio of Taarka Heritage Theatre.

Türnpu's community theatre production How to Sell a Seto?(Kuidas müüa setot?, 2012) participated in the Mayatul festival in 2014 and tackled the issue of minority identity from the perspective of the Setos. Approximately 2000 Setos live in Setomaa and 15-20 000 people live elsewhere in Estonia or Russia. ${ }^{54}$ They claim to have their own language, culture, and national identity, even though they are well assimilated into Estonian culture. The Setos are considered to be the representatives of traditional culture, especially because of their unique multiple-voice singing tradition that has been added to the list of UNESCO's Intangible Cultural Heritage and their original national costumes.

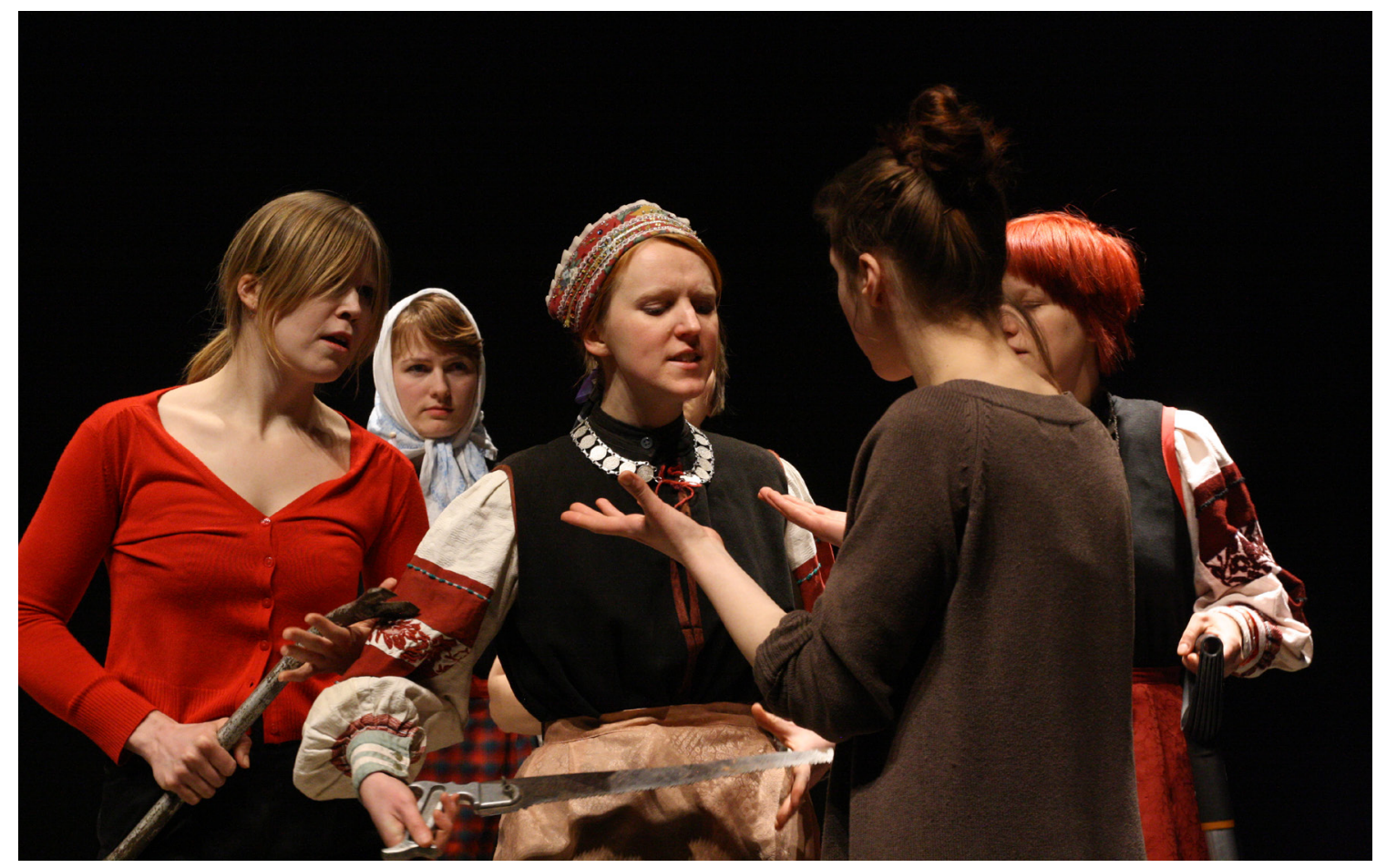

FIGURE 3. How to Sell a Seto? Directed by Anne Türnpu. Taarka Heritage Theatre, 2012. Photo: Arvi Matvei.

51 Sallamaa 1999.

52 It is worth mentioning that an international ethno futurism festival "Pelnian" was held in 2003 in Udmurtia. See http://www.suri.ee/tul/pelnian2.html

53 Moring Helsingin Sanomat 25.11.2012.

54 "Setod." Fenno-Ugria webpage 2020. 
In the production, young Seto women, all of them amateur performers, used both the Estonian and Seto languages to present sincere monologues directly to the spectators or played funny exemplary scenes about the paradoxes of being a Seto. They took an „in-between“ position, changing between the point of view of an insider and one of an outsider. Topics like the commercialization of heritage culture were covered, considering the urge for authenticity on the one hand and the strict need to preserve ones heritage on the other. The performers protested against both these attitudes, against both traditionalism and commercialization. According to Eva-Liisa Linder, How to Sell a Seto? left the impression of a Mayday call from a sinking ship. ${ }^{55}$ The production represented the dilemma of many Finno-Ugric peoples who have a feeling of split personality, torn between the responsibility to preserve their heritage and the attractions of a modern lifestyle and universalist ideologies.

These are just a few examples of Anne Türnpu's works that often use ethnic heritage as material and postdramatic strategies for illuminating controversies and universal features in identity building. Türnpu works mostly outside of big institutional theatres and her productions definitely fall out of the mainstream aesthetics both in Estonia and in the context of Finno-Ugric theatres, thus she herself also represents a kind of minority.

\section{Conclusion}

The construction of transnational Finno-Ugric identity in the theatre occurs separately in different locations, making it a rather implicit, subconsciously perceived intersection of different identities and cultures. Nevertheless, local heritage as well as heritage of the other Finno-Ugric peoples has been considered by the theatre makers to be a valuable resource in identity making, in the search for roots and individuality, especially during the eras of assimilation and globalization.

The theatre festival discussed here was meant to function as a meeting place of the Finno-Ugric peoples but also as a tool of empowerment, establishing and strengthening invisible and vague ties that exist between the peoples and cultures of distant regions. In principle, intercultural festivals like Mayatul have shown that they are able to unite minority identities as part of a larger transnational identity, even if it is just an imagined community, in which unity is constructed through diversity. On the basis of our research discussed above, the impact of the Finno-Ugric theatre festival Mayatul in developing Finno-Ugric theatre aesthetics or identity has so far been rather insignificant. Nevertheless, intercultural festivals either explicitly or implicitly promote cultural diversity on a similar level with biological diversity.

The works of Türnpu are analyzed here not with the aim of setting an aesthetic paragon of Finno-Ugric theatre compared to other artists in the field, but to track her experiments as a constant search for understanding diverse minority identities and finding an indigenous Finno-Ugric theatrical language.

Constructing and exploring the transnational Finno-Ugric identity through the public performative tools of the theatre has clear political and sociopolitical

55 Linder 2019, 82. 
connotations and aims, especially for suppressed minorities. The Finno-Ugric movement (incl. theatre productions and festivals) safeguards minority identities against cultural and political hegemony and is thus a tool and a manifestation of identity politics. Transnational Finno-Ugric identity opposes hierarchical models of identities and identity constructions.

\section{AUTHORS}

Luule Epner is Associate Professor of Estonian literature at the School of Humanities, Tallinn University (Estonia). Her research interests include relationships between dramatic texts and theatre performances, theory and practices of postdramatic theatre, and drama theory. She has widely published on relevant topics in different journals, including Sign Systems Studies, Methis, Interlitteraria, Nordic Theatre Studies, etc. She is the author of Draamateooria probleeme I-II (Problems of Drama Theory, 19921994), and co-author of Eesti kirjanduslugu (Estonian Literary History, 2001), and Eesti sõnateater 1965-1985 (Estonian Drama Theatre 1965-1985, 2015). Her recent book, Mängitud maailmad (Worlds in Play), was published in 2018.

Anneli Saro is Professor of Theatre Research at the University of Tartu (Estonia). Saro has published articles and books on Estonian theatre history and system, performance theory, and audience research. Currently, she is working on two projects: a comparative analysis of amateur theatre fields in small European countries and the poetics of playing.

Saro has been a convener of the international working groups Project on European Theatre Systems (2004-2008, 2017-) and Theatrical Event (2011-2017). She has been active as the Editor-in-Chief of Nordic Theatre Studies (2013-2015) and as a member of the executive committee of the International Federation for Theatre Research (2007-2015).

\section{REFERENCES}

Arukask, Madis. 2018. "Soomeugrilusest eesti rahvuspildis - kas jagatud emotsioon või hägune küsitavus?” Keel ja Kirjandus 1-2, 104-117.

Bauman, Zygmunt. 2004. Identity: Conversations with Benedetto Vecchi. Cambridge: Polity Press.

Cagnoli, Sébastien. 2013. "The role of drama in the construction of national identities in the Ural-Volga area, through examples of Finno-Ugric interaction." Researchgate, https://www. researchgate.net/publication/328842367 (6.7.2020).

ETY=EestiEtümoloogiasõnaraamat,https://www.eki.ee/dict/ety/index.cgi?Q=tuli\&F=M\&C06=et (15.2.2020).

Hall, Stuart. 1996. "Introduction: Who needs identity?" In Stuart Hall, Paul du Gay (eds.). 
Questions of Cultural Identity. Los Angeles, London etc.: Sage, 1-17.

Holdsworth, Nadine. 2014. "Introduction." In N. Holdsworth (ed.). Theatre and National Identity: Re-imagining Conceptions of Nation. London, New York: Routledge, 1-16.

Kuutma, Kristin. 1998. "Festival as communicative performance and celebration of ethnicity." Folklore 7, https://www.folklore.ee/folklore/vol7/festiva.htm (12.1.2020).

Kuutma, Kristin. 2005. "Vernacular religions and the invention of identities behind the FinnoUgric Wall." Temenos : Nordic Journal of Comparative Religion, 41:1, 51-76.

Laasik, Andres. 1992. "Surevate rahvaste teatri pidu". Teater. Muusika. Kino 7, 63-65.

Linder, Eva-Liisa. 2019. "Three Phases of the Theatrical Public Sphere in Estonian Theatre." Nordic Theatre Studies 31:1, 73-91.

Masing, Uku. 1993. "Hüpoteetilist eesti keele psühholoogiast." In Uku Masing. Vaatlusi maailmale teoloogi seisukohalt. Tartu: IImamaa, 51-55.

Prozes, Jaak. 2012. "Hõimuliikumine ja Fenno-Ugria Asutus." Soome-ugri sõlmed 2010-2011. Tallinn: Fenno-Ugria, 104-114.

Prozes, Jaak. 2014. "Hõimuliikumise unistused ja reaalsus 1980ndate lõpus ja 1990ndate alguses." Soome-ugri sõlmed 2013. Tallinn: Fenno-Ugria, 16-19.

Raudalainen, Viia-Kadi. 2019. "Muljeid 12. soome-ugri teatrifestivalilt Majatul." Soome-ugri sõlmed 2018. Tallinn: Fenno-Ugria, 128-132.

Reinelt, Janelle. 2005. "National signs: Estonian identity in performance." Sign Systems Studies, 33:2, 369-378.

Schoenmakers, Henri. 2007. "Festivals, theatrical events and communicative interactions." In Temple Hauptfleisch, Shulamith Lev-Aladgem, Jacqueline Martin, Willmar Sauter, Henri Schoenmakers (eds.). Theatrical Events, Politics and Culture. Amsterdam, New York: Rodopi.

Smith, Anthony D. 1991. National identity. Reno: University of Nevada Press.

Stoeltje, Beverly J. 1992. "Festival." In Richard Bauman (ed.). Folklore, Cultural Performances and Popular Entertainments. New York, Oxford: Oxford University Press, 261-271.

Suits, Gustav. 2002. "Kultuur ja sõda: 1905-1915." - Vabaduse väraval. Tartu: Ilmamaa, 64-72.

Thiel, Markus and Rebecca Friedman. 2012. "Introduction: culture and narratives of transnational belonging." European Identity and Culture: Narratives of Transnational Belonging. London, New York: Routledge, 1-16.

Türnpu, Anne e-mail 21.3.2019 to the author(s).

Türnpu, Anne interview 5.2.2020. Interviewed by the author(s). 
Viluoja, Eha. 2013. "Fenno-Ugria jututuba: Sugrierroriga Saranskis." Soome-ugri sõlmed 2012. Tallinn: Fenno-Ugria, 143-153.

\section{Newspapers}

Ala, Janar. 2011. "Kus viga näed laita, seal ära aita - teater, mis uurib sugri tehnoteadvust." Postimees, 31.8.2011.

Linder, Eva-Liisa. 2011. "Sugri error on nihe meie maailma ja realiteedi vahel. Interview with Anne Türnpu." Sirp, 26.8.2011.

Moring, Kirsikka. 2012. "Kaikki me olemme venäläisiä." Helsingin Sanomat, 25.11.2012.

Kulbayeva, Natalja. 2009 = Кульбаева Наталиа. “Фестиваль 'Майатул': пройденное и перспективы." Финно-угорский культурный центр Российской Федерации webpage, http://www.finnougoria.ru/news/publications/9247/ (15.3.2019)

Sallamaa, Kari. 1999. "Uku Masing as the Pioneer of Ethnofuturism." Suri web archaive, http:// www.suri.ee/etnofutu/vanaisad/masing/sall-uku.html (7.7.2020).

\section{Webpages}

"Finno-Ugrians, who are they?" Eesti rahvaluule webpage,_http://www.folklore.ee/ugri/fu/ whougri.html (23.2.2020).

"Finno-Ugric Peoples." Fenno-Ugria webpage,_https://eng.fennougria.ee/peoples/ (20.2.2020).

"Setod." Fenno-Ugria webpage,_https://fennougria.ee/rahvad/laanemeresoome-rahvad/ eestlased/setod/ (25.2.2019).

"Soome-ugri teater ei ole surnud - see elab!" Fenno-Ugria webpage, https://fennougria.ee/ soomeugriteater-ei-ole-surnud-\%E2\%88\%92-see-elab/ (28.2.2020). 